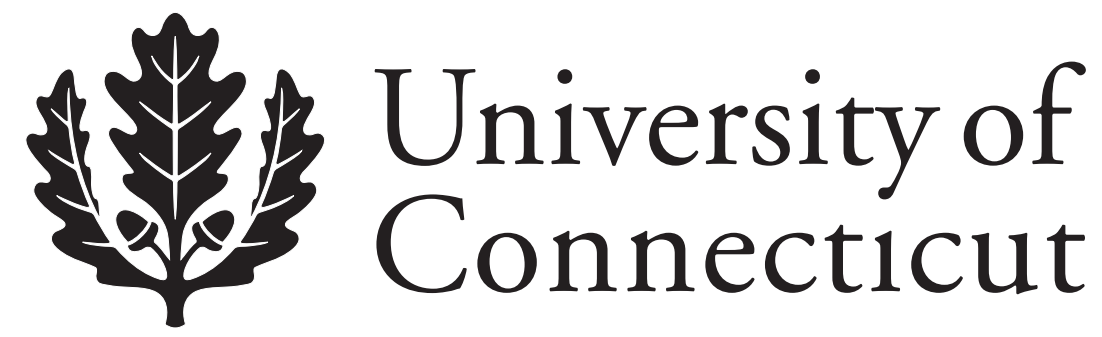

Department of Economics Working Paper Series

The Determinants of State-Level Caps on Punitive Damages: Theory and Evidence

Thomas J. Miceli

University of Connecticut

Michael P. Stone

Quinnipiac University

Working Paper 2010-25

October 2010

341 Mansfield Road, Unit 1063

Storrs, CT 06269-1063

Phone: (860) 486-3022

Fax: (860) 486-4463

http://www.econ.uconn.edu/

This working paper is indexed on RePEc, http://repec.org/ 


\begin{abstract}
Under the standard economic model of torts, punitive damages correct for imperfect detection. Incorporating litigation costs into the model provides a justification for punitive damage caps. At the optimum, caps balance deterrence against the cost of litigation. Empirical testing of the model is performed via Cox proportional and parametric hazard analyses, using a panel dataset from 1981 to 2007. The results reveal a positive relationship between judicial and legal expenditures (a proxy for legal costs) and cap enactment, and a negative relationship between state GSP (a proxy for damages) and cap enactment. Cap enactment is also influenced by political ideology.
\end{abstract}

Journal of Economic Literature Classification: K13, K41

Keywords: Deterrence, litigation costs, punitive damages, statutory caps

We acknowledge the helpful advice of Stephen Ross and the comments of participants at the Department of Economics Brownbag, University of Connecticut, November 2009. 


\section{The Determinants of State-Level Caps on Punitive Damages: Theory and Evidence}

\section{INTRODUCTION}

Despite the traditional function of the tort system to "make victims whole," punitive damages are monetary awards set at levels greater than pure compensation. These damages are imposed to punish and deter wrongdoing and are most frequently awarded in cases involving business-related activity. In recent years, however, some states have placed statutory ceilingsconventionally known as damage caps_ — on the magnitude of punitive damages awards. The purpose of this paper is to develop a theory of these damage caps and then to test the implication of that theory using state-level data.

According to the standard economic model, punitive damages are imposed as a solution to the underdetection problem (Cooter, 1982, 1989). If an injurer can escape liability for a tort with a positive probability, then in those cases in which the injurer is in fact held liable, the injurer's total liability (compensatory plus punitive damages) "should equal the harm multiplied by the reciprocal of the probability that [the injurer] will be found liable when he ought to be" (Polinsky and Shavell, 1998: p. 889). There are a number of reasons why injurers are sometimes able to escape liability. First, victims may have difficulty establishing the essential elements of a valid cause of action at trial. This is especially true in cases where victims have difficulty proving causation as the result of a background risk of injury. Second, litigation costs may outweigh the potential benefit of filing suit and hence deter some victims from ever pursuing a valid cause of action. Finally, injurers may sometimes have an opportunity to conceal their identity or engage in other conscious efforts to evade liability. While the foregoing considerations justify the imposition of punitive damages, courts regularly neglect them, 
focusing instead on the mental state of the injurer. For example, courts tend to focus on whether a tortfeasor's actions were intentional or malicious (Polinsky and Shavell, 1998: pp. 898-899). ${ }^{1}$ (Of course, one might argue that intent could lead injurers to take conscious efforts to avoid detection. $)^{2}$

The empirical literature on punitive damages has been primarily devoted to examining the frequency, magnitude, and determinants of punitive damage awards. For instance, Eisenberg, et al. (1997) surveyed tort cases decided in state courts between 1991 and 1992 and found that only $6 \%$ of cases won by plaintiffs involved punitive damages. However, the study was not able to identify a predictable pattern regarding when they were awarded. Indeed, Polinsky (1997) argued that the results were consistent with the possibility that punitive damages are randomly awarded. Karpoff and Lott (1999) reached a similar conclusion based on a sample of lawsuits filed against public corporations during 1985-1996 (most of which were products liability). Both studies, though, did find that the level of punitive damages was strongly correlated with the size of compensatory damages, as did the study by Schmit, Pritchett, and Fields (1988). ${ }^{3}$ Finally, Hersch and Viscusi (2004) found that juries were more likely than judges to award punitive damages, and that jury awards were generally larger. A factor complicating any study of punitive damages awards, however, is that cases involving punitive damages are frequently reversed or reduced on appeal (Landes and Posner, 1987: pp. 302-307; Shanley, 1991).

\footnotetext{
${ }^{1}$ See, e.g., City of Newport v. Fact Concerts, Inc., 454 U.S. 247 (1981).

${ }^{2}$ There are alternative theoretical justifications for punitive damages in the literature. Biggar (1995) maintains that punitive damages ensure that victims will be fully compensated and hence will not take inefficient avoidance actions. Sharkey (2003) argues that punitive damages benefit victims who are not before the court. In other words, punitive damages compensate for "societal damages." Shavell (2004: p. 245) claims that punitive damages can be justified when wrongdoers obtain illicit utility from their illegal acts (i.e., utility not recognized in the social welfare function). Finally, punitive damages have been justified to deter wealthy injurers from wrongdoing since compensatory damages "mean less" to wealthy, as opposed to poor, injurers (Chu and Huang, 2004).

${ }^{3}$ This finding is consistent with the current constitutional law governing punitive damages awards.
} 
Economists clearly have an imperfect understanding of the determinants of punitive damages, but they know even less about the factors underlying the enactment of statutory caps on punitive damages. This paper begins to remedy this deficiency by examining caps from both a theoretical and empirical perspective. In terms of theory, we ask what economic justifications (if any) there are for limiting punitive damages. The simple "deterrence" theory described above does not provide an adequate basis because a limit on punitive damages only blunts the deterrence function of tort law. However, when litigation costs are taken into account, imposing a limit potentially provides an offsetting benefit by reducing the number of costly suits filed by plaintiffs. To test the implications of our theory, we conduct an empirical analysis of the factors that determine a state's decision of whether to enact a cap. In particular, we look at the determinants of statutes promulgated in an effort to abrogate a state's common law of punitive damages.

Previous empirical studies of damage caps have examined their impact on accident litigation while treating caps as exogenous. For example, Yoon (2001) found that a cap on noneconomic damages, including punitive damages, enacted by Alabama reduced average damage awards relative to a control group of states. Rubin and Shepherd (2007) found that caps on noneconomic damages and an increased evidentiary standard for punitive damages were both associated with a reduction in the accidental death rate. Born, Viscusi, and Baker (2009) found that caps on non-economic damages reduced medical malpractice losses and increased insurer profitability (also see Viscusi and Born, 2005). Avraham (2007) similarly found that caps on non-economic damages had a significant effect in reducing the number of malpractice claims, average awards, and total payments (though the last effect was weak). Caps on punitive damages, however, did not have a significant effect. 
The remainder of the paper is organized as follows. Section 2 develops the theoretical analysis of damage caps. Section 3 provides a brief history of damages caps in the United States. Section 4 describes the empirical strategy and the data to be used. Section 5 then presents the results. Finally, Section 6 offer concluding comments.

\section{THEORETICAL ANALYSIS}

The standard economic theory of punitive damages, based on the underdetection problem, can be formalized as follows. Let $q$ be the probability, as perceived by the injurer, that a victim will detect and prove that the injurer is responsible for the victim's damages, given by $D$. Since a lawsuit is the only route by which the injurer faces liability, $q<1$ leads to underdeterrence if compensation is limited to compensatory damages. Suppose, however, that the court is permitted to add punitive damages of $P$ in addition to compensatory damages in those cases in which the injurer is found liable. (We assume throughout that liability is strict, so the injurer is held liable whenever causation is established.) The injurer's expected liability per accident is therefore $q(D+P)$. In order to achieve optimal deterrence, this term must equal actual damages per accident, or $q(D+P)=D$, which implies that:

$$
P=\left(\frac{1-q}{q}\right) D .
$$

Thus, punitive damages should be increasing in $D$, decreasing in $q$, and zero when $q=1$ (i.e., when detection is certain).

Note further that according to (1), punitive damages should theoretically increase without

limit as $q$ becomes very small. Otherwise, deterrence is mitigated. Based on this result, Polinsky 
and Shavell (1998: p. 900) conclude that, "in the absence of systematic bias [in jury awards of punitive damages], caps are inappropriate."

Adding litigation costs to the model, however, may alter this conclusion since their presence creates potentially offsetting effects. On one hand, litigation costs reinforce the need for punitive damages because they represent another way that injurers are sometimes able to avoid liability. In particular, victims whose expected recovery is less than the cost of obtaining a judgment at trial will not sue, even if detection is perfect (Hylton, 1990). On the other hand, costly litigation reduces the benefits of lawsuits as a means of inducing injurers to be careful (Shavell, 1982). Thus, the fact that punitive damages increase the number of suits, and hence litigation costs, offsets their attractiveness as a deterrent.

To evaluate these countervailing effects, we extend the imperfect detection model of punitive damages to incorporate costly litigation and an endogenous number of suits. First, suppose that victims have a cost of filing suit equal to $c_{v}$ and that this cost is not compensated by the losing party. Thus, if an accident occurs and the victim's probability of proving causation is $q$, the victim will file suit if and only if:

$$
q(D+P) \geq c_{v},
$$

or, if and only if:

$$
q \geq \frac{c_{v}}{D+P} \equiv \hat{q}(P)
$$

Now suppose that $q$ varies across the population of potential victims according to the distribution function $F(q)$, reflecting, for example, differences in the ability of victims to prove causation. In the event of an accident with a randomly chosen victim, the injurer therefore computes his conditional probability of facing suit to be $1-F(\hat{q}(P))$. Since $\hat{q}(P)$ is decreasing in $P$, it follows 
that the probability of suit is increasing in $P$. As a result, an increase in punitive damages increases the expected number of suits.

Now consider deterrence. Let $r(x)$ be the probability of an accident as a function of the injurer's investment in care, $x$, where $r^{\prime}<0, r^{\prime \prime}>0$. Thus, under strict liability and endogenous lawsuits, the injurer chooses $x$ to minimize:

$$
x+r(x)\left[\int_{\hat{q}(P)}^{1}\left[q(D+P)+c_{i}\right] f(q) d q\right]
$$

where $c_{i}$ is the injurer's litigation costs. The term in square brackets is the injurer's expected costs (liability plus litigation costs) in the event of an accident. To conserve on notation, call this term $E C(P)$. The injurer's optimal care choice, denoted $\hat{x}(P)$, therefore solves:

$$
1+r^{\prime}(x) E C(P)=0
$$

Performing comparative statics on (4) reveals that

$$
\frac{\partial \hat{x}}{\partial P}>0
$$

which follows from the fact that $\partial E C(P) / \partial P>0$. Thus, an increase in punitive damages increases the injurer's level of care. This occurs for two reasons. First, the injurer faces greater liability per suit, and second, the injurer expects to face more suits. These two effects constitute the deterrence benefits of punitive damages.

Let us now turn to the derivation of the socially optimal level of punitive damages in the presence of litigation costs. Social costs in the current model are given by:

$$
S C=\hat{x}(P)+r(\hat{x}(P))\left\{D+[1-F(\hat{q}(P))]\left(c_{i}+c_{v}\right)\right\}
$$

where the term in braces equals damages per accident plus expected litigation costs. The derivative of this expression with respect to $P$ is: 


$$
\frac{\partial S C}{\partial P}=\left\{1+r^{\prime}(\hat{x})\left[D+(1-F(\hat{q}(P)))\left(c_{i}+c_{v}\right)\right]\right\}\left(\frac{\partial \hat{x}}{\partial P}\right)-r(\hat{x}) f(\hat{q})\left(c_{i}+c_{v}\right)\left(\frac{\partial \hat{q}}{\partial P}\right) .
$$

The first term on the right-hand side represents the deterrence effect of $P$, while the second term represents the litigation cost effect. The latter term is clearly positive (given $\partial \hat{q} / \partial P<0$ ), which reflects the increased number of lawsuits as the level of punitive damages is raised. The sign of the deterrence effect, however, is ambiguous. To determine its sign, substitute (4) into the first term in (7) and rearrange to obtain:

$$
r^{\prime}(\hat{x})\left\{D+[1-F(\hat{q}(P))] c_{v}-\int_{\hat{q}(P)}^{1} q(D+P) f(q) d q\right\}\left(\frac{\partial \hat{x}}{\partial P}\right)
$$

Now set $P=0$, in which case $(8)$ reduces to:

$$
r^{\prime}(\hat{x})\left\{D+\left[1-F\left(c_{v} / D\right)\right] c_{v}-\int_{c_{v} / D}^{1} q D f(q) d q\right\}\left(\frac{\partial \hat{x}}{\partial P}\right)
$$

Since the expression in braces is clearly positive (reflecting the fact that injurers fail to fully internalize the social cost of accidents), the overall sign of this term is negative, given that $r^{\prime}<0$. Thus, in the absence of punitive damages there is underdeterrence. It follows that the deterrence component of social costs can be reduced by imposing punitive damages (i.e., by setting $P>0$ ). These gains, however, must be weighed against the resulting increase in litigation costs. Assuming an interior solution, (7) equals zero, or: ${ }^{4}$

$$
\begin{aligned}
-r^{\prime}(\hat{x})\left\{D+[1-F(\hat{q}(P))] c_{v}-\int_{\hat{q}(P)}^{1} q(D+P) f(q) d q\right\}\left(\frac{\partial \hat{x}}{\partial P}\right)= & \\
& -r(\hat{x}) f(\hat{q})\left(c_{i}+c_{v}\right)\left(\frac{\partial \hat{q}}{\partial P}\right) .
\end{aligned}
$$

\footnotetext{
${ }^{4}$ This assumes that the second order condition holds.
} 
Several implications follow from (10). First, since the right-hand side is positive, the left-hand side must also be positive. Thus, at the optimum there is some underdeterrence. Intuitively, when litigation is costly, punitive damages should only be increased to the point where the marginal benefit in terms of increased deterrence equals the marginal increase in litigation costs. This conclusion mirrors a well-known result from the economics of law enforcement; namely, that when apprehension is costly, the expected fine is less than the harm caused by the illegal act, which also results in some underdeterrence (Polinsky and Shavell, 2000: pp. 53-54).

Second, the zero-litigation-cost (perfect deterrence) outcome emerges as a special case of (10). To see this, note that if $c_{i}=c_{v}=0,(10)$ reduces to:

$$
-r^{\prime}(x)[D-\bar{q}(D+P)]\left(\frac{\partial \hat{x}}{\partial P}\right)=0
$$

where $\bar{q}$ is the expected value of $q$. It follows that:

$$
P^{*}=\left(\frac{1-\bar{q}}{\bar{q}}\right) D
$$

which is the analog to (1).

Finally, the preceding theory provides a possible economic rationale for state-level caps on punitive damages. As argued above, a theory of punitive damages based purely on deterrence does not justify a limit on $P^{*}$. However, when litigation costs are incorporated into the theory, a cap on punitive damages may be justified. Specifically, an examination of (10) suggests that a cap will become more desirable as the overall cost of lawsuits, $c_{i}+c_{v}$, increases (since the marginal litigation cost term increases), and less desirable as the damages per accident increase 
(since the marginal benefit term increases). ${ }^{5}$ Empirical testing of these predictions requires a broad understanding of the history behind punitive damages caps. Accordingly, we devote the next section to a brief review of the history of punitive damages caps as a prelude to the empirical analysis.

\section{A BRIEF HISTORY OF PUNITIVE DAMAGE CAPS}

Despite being a permissible remedy under common law, punitive damages were infrequently awarded until the early $20^{\text {th }}$ century. ${ }^{6}$ In fact, these early awards were usually limited to cases involving intentional torts or criminal behavior (Ausness, 1985: p. 7). Now, however, punitive damages are awarded under a variety of different legal regimes. But, because their use in products liability cases has probably attracted the most public attention, the evolution of punitive damages - and the resulting state-level caps - is best understood by examining the historical application of punitive damages in products liability law.

The use of punitive damages in products liability law arguably began in the late 1960s, ${ }^{7}$ though they were only used sporadically during this period. The trend to award punitive damages did not gain momentum until 1979 when the Alaskan Supreme Court upheld a trial court's award of punitive damages for the defective design of a revolver in Sturm, Ruger \& Co. v. Day. ${ }^{8}$ Two years later, the application of punitive damages in products liability garnered

\footnotetext{
${ }^{5}$ Neither of these effects is a true comparative static since the complexity of (10) does not yield unambiguous results. Predictions therefore reflect perceived dominant effects.

${ }^{6}$ See Rustad and Koenig (1993: p. 1303), who argue that punitive damages gained acceptance in the early twentieth century as a way to protect the consumer.

${ }^{7}$ Ausness cites Toole v. Richardson-Merrell, Inc., 60 Cal. Rptr. 398 (Cal. Ct. App. 1967) and Roginsky v. Richardson-Merrell, Inc., 378 F.2d 832 (2d Cir. 1967) to support this proposition.

${ }^{8} 594$ P.2d 38 (Alaska, 1979), modified, 615 P.2d 621 (Alaska, 1980), cert. denied, 454 U.S. 894 (1981).
} 
substantial national attention following the ruling in Grimshaw v. Ford Motor Co. (the Ford Pinto case). ${ }^{9}$

In Grimshaw, the plaintiff was awarded $\$ 2.5$ million in compensatory damages and $\$ 125$ million in punitive damages for injuries sustained as the result of the defective design of the Ford Pinto. Although the punitive damages award was later reduced by the trial court judge to $\$ 3.5$ million on remittitur, the case provided the impetus for future courts to award punitive damages. Indeed, in the four years following Grimshaw, the number of cases involving punitive damages "escalated substantially" in areas such as motor vehicle manufacturing, pharmaceuticals, and asbestos (Ausness, 1985: pp. 23- 24). ${ }^{10}$

As courts became more willing to impose punitive damages in the wake of Grimshaw, however, a debate arose over whether to impose statutory caps on such awards. This debate hinged on a balancing of the effect of punitive damages on insurance premiums versus corporate responsibility. ${ }^{11}$ The insurance industry lobbied state legislators to reform the law of punitive damages, citing a perceived "insurance crisis."12 It was feared that since jurors were unconstrained in awarding punitive damages, they would be inclined to impose sizeable, yet unjustified, awards. ${ }^{13}$ This spurred "widespread alarm and cries for tort reform throughout the United States" (O’Connell, 1987: p. 317). At the same time, however, consumer advocacy groups lobbied in opposition to punitive damages caps, claiming the need to promote corporate responsibility as their motive.

${ }^{9} 174$ Cal. Rptr. 348 (Cal. 1981).

${ }^{10}$ From 1975 to 1984 , products liability filings surged by $272 \%$, while the remainder of torts increased by $17 \%$. Galanter (1986: p. 21).

${ }^{11}$ See, e.g., "Damages Cap Debated," The Washington Post (February 6, 1986) (stating that Virginia's Senate Court of Justice Committee heard testimony regarding unjustifiably high insurance premiums and that the application of a punitive damages cap would be unfair to victims of corporate wrongdoing.)

${ }^{12}$ See Greene, Goodman, and Loftus (1991) for a description of the manners in which the insurance industry utilized various forms of media to "join the battle against lawsuit abuse."

${ }^{13}$ See Viscusi (2004) (stating, "[m]uch of the concern with respect to punitive damages stems from the imprecise guidance that juries are given in setting the award levels."). 
In the years following Grimshaw, several states nevertheless enacted legislation aimed at reducing the incidence of punitive damages. ${ }^{14}$ Between 1985 and 1989, twelve states, beginning with Montana, imposed some form of a damage cap. But, after this initial surge, a period of relative inactivity followed. Indeed, from 1990 to 1993, only one further state, North Dakota, imposed a cap on punitive damages. Apparently, by the early 1990s, caps on punitive damages had lost their appeal.

However in 1994, the notorious case of Liebeck v. McDonald's Restaurants ${ }^{15}$ brought the issue of punitive damages back to the national spotlight. In Liebeck, the jury awarded the plaintiff $\$ 160,000$ in compensatory damages and $\$ 2.7$ million in punitive damages for injuries sustained from the defendant's allegedly defective and dangerous coffee. ${ }^{16}$ Although the judge later reduced the punitive damages award to $\$ 480,000$, the case received attention in various media outlets, including newspapers, television news coverage, magazines, talk shows, late night television, and even corporate advertisements (McCann, Haltom, and Bloom, 2001: pp. 163166). The ruling apparently served as a catalyst for further tort reform, as seven states enacted caps on punitive damages between 1995 and $1998 .{ }^{17}$

By the end of the twentieth century, the trend to cap punitive damages had again slowed; from 1999 to 2007, only four additional states enacted caps. Overall, between the Appellate

\footnotetext{
${ }^{14}$ In addition to capping punitive damages, some state legislatures have enacted legislation that elevates evidentiary requirements. Additionally, some states have passed laws requiring a fraction of punitive damages awards to be paid to a state fund.

${ }^{15}$ Docket No. D-202 CV-93-02419 (Bernalillo County, N.M. Dist. Ct. Aug. 18, 1994). See McCann, Haltom, and Bloom (2001) for an overview of the Liebeck case and the verdict's ensuing media frenzy.

${ }^{16}$ The plaintiff in Liebeck had purchased a cup of coffee from a drive-through window at a McDonald's restaurant. She then placed the cup between her legs, and while attempting to remove the lid, spilled the coffee on her lap, causing third degree burns to her thighs, buttocks, genitals, and groin. She sued McDonald's, claiming that the coffee was a defective and dangerous product since it was being served at an extremely hot temperature and without adequate warning.

${ }^{17}$ Maine capped punitive damages in wrongful death actions during this time. See Me. Rev. Stat. 18-A, § 2-804 (1997). However, since wrongful death actions are a small subset of all possible tort claims and the cause of action was not originally actionable at common law, Maine's cap is excluded from the empirical analysis.
} 
Court's ruling in Grimshaw and 2007, 24 states put into effect some sort of cap on common law awards of punitive damages. Figure 1 schematically depicts the time frame of enactment by state.

\section{EMPIRICAL ANALYSIS}

The empirical analysis in this paper departs from previous studies of damage caps by treating caps as endogenously determined. This section describes the empirical strategy and the data used in this effort.

\subsection{The Hazard Model}

The method we use to study the enactment of damage caps is hazard analysis, sometimes known as survival analysis. Instead of utilizing a binary dependant variable to reflect whether a state has enacted a cap at a particular point in time, this approach generates properly censored times-to-enactment as the dependant variable. These times-to-enactment reflect the length of time that a state has "survived" before enacting a cap.

A hazard analysis using properly censored times-to-enactment is superior to other regression techniques for dealing with discrete, binary dependant variables (e.g., probit or logit regression) for a number of reasons. First, probit and logit regressions require unreasonable distributional assumptions regarding the error term. In particular, the error term of the probit regression is assumed to follow a normal distribution, while the error term of the logit regression is assumed to be an independent and identically-distributed extreme value. As Figure 2 shows, state legislatures' voting behavior since the early 1980s has followed a crude bimodal distribution. Thus, there is little reason to believe that the error term will be normal or extremevalued. In addition, unlike probit and logit regression, hazard analysis allows us to exploit the 
influence of time on cap enactment. Lastly, since not all states have enacted caps, the times-toenactment are right censored. Censored data are not properly handled by traditional probit and logit regression. Hazard analysis is therefore superior to probit and logit regression for the problem at hand.

For purposes of the analysis, we assume that once a punitive damages cap is enacted, it will remain enacted forever. This assumption is somewhat unrealistic since Alabama ${ }^{18}$ and Ohio $^{19}$ have struck down their punitive damage caps as unconstitutional. As a consequence, the model can be interpreted as predicting the first time that a state will enact a cap on common law awards of punitive damages.

The hazard model is formulated as follows. Let $T$ be a random variable representing the time-to-enactment of a punitive damage cap, where $t$ is the realized value for a particular state. The survivor function, $S(t)$, is defined to be the probability that a state does not enact a cap until after time $t .^{20}$ It is a non-increasing function in $t$ and is given by

$$
S(t)=\operatorname{Pr}(T>t)=1-F(t)
$$

where $F(t)$ is the distribution function for $T$. The hazard rate, $h(t)$, is the instantaneous rate of enactment. In other words, it is the probability of enactment given that enactment has not already occurred. Formally,

$$
h(t)=\frac{f(t)}{S(t)}
$$

\footnotetext{
${ }^{18}$ In Henderson v. Alabama Power Co., 627 So.2d 878 (Ala. 1993), the Alabama Supreme Court struck down Alabama's cap on punitive damages, holding that it violated one's right to a trial by jury as provided by the Alabama Constitution.

${ }^{19}$ In State ex rel. Ohio Academy of Trial Lawyers v. Sheward, 715 N.E.2d 1062 (Ohio, 1999), the Ohio Supreme Court invalidated a punitive damages cap under the one-subject rule. Specifically, the court found that a punitive damages cap that applied to "tort and other civil actions" was overly broad since it covered unrelated areas.

${ }^{20}$ See Klein and Moeschberger (1997) for a detailed explanation of hazard models.
} 
where $f(t)$ is the density function of $F(t)$. If a hazard rate is not derived from the data, it is known as a hazard function, and it can assume different underlying distributions, including exponential, Weibull, gamma, and others. ${ }^{21}$

For state $j$, the hazard rate is some function $g(\cdot)$ such that:

$$
h_{j}(t, x)=g\left(t, \beta_{0}+x_{j} \beta_{x}\right)
$$

where $x$ is a vector of covariates for state $j$. This model can be parameterized as follows:

$$
h_{j}(t, x)=h_{0}(t) \exp \left(\beta_{0}+x_{j} \beta_{x}\right)
$$

where the hazard facing state $j$ is multiplicatively proportional to the baseline hazard, $h_{0}(t)$. Note that the covariates are not a function of the baseline hazard; this is a Cox model, conventionally known as the proportional hazards model.

The Cox proportional hazards model generates an empirically-derived hazard function. Although the Cox model is not burdened by any distributional assumption regarding the shape of the underlying hazard function, it assumes that the hazard ratios are not influenced by time. However, by positing a certain functional form for the underlying hazard, we are able to exploit the influence of time on the hazard that a state enacts a cap. As a result, the model provides us with better estimates for our covariates. The hazard function under this parametric model is specified as follows:

$$
h_{j}(t, x(t))=h_{0}(t) \exp \left(\beta_{0}+x_{j}(t) \beta_{x}\right) \text {, }
$$

where the covariates are no longer separable from time. The Weibull distribution is most common and yields the following hazard function:

$$
h(t)=\lambda \alpha t^{\alpha-1}
$$

\footnotetext{
${ }^{21}$ See Klein and Moeschberger (1997: p. 37) for the hazard rate, survival function, probability density function, and expected lifetime for common parametric distributions.
} 
where $\lambda$ is a scale parameter, $\alpha$ is a shape parameter, and $\alpha, \lambda>0$. Note that the Weibull function can only replicate monotonically increasing or decreasing hazards.

Finally, there exists the possibility of unobserved heterogeneity stemming from possible omitted variable bias in the parametric hazard model. Following Nanda (2006) and de Figueiredo and Vanden Bergh (2004), we incorporate heterogeneity into the model by imposing a continuously distributed heterogeneity term. In this paper, we use the gamma distribution to control for unobserved heterogeneity.

\subsection{The Data}

For the different hazard analyses, we used a rich panel containing data for 40 states from 1981 to 2007 , where the starting point is strategically chosen to coincide with the year in which the California Supreme Court rendered the Grimshaw decision. The ruling in Grimshaw is presumed to mark the beginning of the hazard of a cap faced by states. This presumption is consistent with the evolution of punitive damages awards in products liability law and Ausness' (1985: p. 23) observation that despite being awarded infrequently historically, "[t]he number of punitive damages claims against product manufacturers has escalated substantially in the four years since Grimshaw." Additionally, the historical significance of the Liebeck case also suggests that it may have had an influence on cap enactment. To account for this, we will include a dummy variable for the Liebeck ruling in some of the regressions presented below.

The panel omits data from those states that either (i) prohibit limitations on punitive damages under constitutional law, or (ii) prohibit the application of punitive damages at common law. Three state constitutions prohibit limitations on punitive damages awards: Arizona, ${ }^{22}$

\footnotetext{
22 "No law shall be enacted in this State limiting the amount of damages to be recovered for causing the death or injury of any person." Ariz. Const. Art. 2, § 31.
} 
Kentucky, ${ }^{23}$ and Wyoming. ${ }^{24}$ Since a cap on punitive damages requires a constitutional amendment, these states do not face the same hazard as those states without constitutional limitations. Moreover, long before 1981, seven states prohibited punitive damages at common law: Connecticut, Louisiana, Massachusetts, Michigan, Nebraska, New Hampshire, and Washington. In Connecticut, although punitive damages are permitted to cover litigation costs, including reasonable attorney's fees, these damages are only imposed to "make victims whole." 25 Since the recovery of damages greater than pure compensation is prohibited at common law, punitive damages have been effectively capped at zero in Connecticut. In Louisiana, punitive damages were prohibited at common law, and this cap dates back to at least $1932 .{ }^{26}$ Similarly, in Massachusetts, ${ }^{27}$ Michigan, ${ }^{28}$ Nebraska,${ }^{29}$ New Hampshire, ${ }^{30}$ and Washington, ${ }^{31}$ punitive damages have been prohibited at common law, dating back to the 1800s. Because these ten states are anomalies, we omit them from the empirical analysis.

The dummy variable $P D \_C a p$ takes the value ' 1 ' if state $j$ enacted a cap on punitive damages before July $1^{\text {st }}$ of time $t$. Avraham (2010) provides these data. ${ }^{32}$ As noted above, once a cap is enacted, it is presumed that it will remain active forever, and therefore, situations in which a cap is struck down as unconstitutional are ignored. As a result, the dependant variable reflecting the time-to-enactment is generated as the difference between 1981 and the first time in

\footnotetext{
23 "The General Assembly shall have no power to limit the amount to be recovered for injuries resulting in death, or for injuries to person or property." Ky Const. § 54.

24 "No law shall be enacted limiting the amount of damages to be recovered for causing the injury or death of any person.” Wyo. Const. Art. $10 \S 4($ a).

${ }^{25}$ As stated by the court in Doroszka v. Lavine, "the purpose [of punitive damages] is not to punish the defendant for his offense but to compensate the plaintiff for his injuries." Doroszka v. Lavine, 150 A. $692-93$ (Conn., 1930).

${ }^{26}$ See Killebrew v. Abbot Laboratories, 359 So.2d 1275 (La., 1932).

${ }^{27}$ See Burt v. Advertiser Newspaper Co., 28 N.E. 1 (Mass., 1891).

${ }^{28}$ See Ford v. Cheever, 63 N.W. 975 (Mich., 1895).

${ }^{29}$ See Boyer v. Barr, 8 Neb. 68 (1878).

${ }^{30}$ See Fay v. Parker, 53 N.H. 342 (1872).

${ }^{31}$ See Spokane Truck \& Dray Co. v. Hoefer, 25 P. 1072 (Wash., 1891).

${ }^{32}$ The substance of state caps varies in ways that would be difficult to quantify. Thus, we simply treat it as a qualitative variable.
} 
which the dummy variable $P D \_C a p$ takes the value ' 1 ', regardless of whether the cap was later modified by the state legislature or the courts.

The model in Section 2 predicted that a cap is more desirable as litigation costs increase, and less desirable as accident losses increase. We include several explanatory variables to test these predictions. The variable Jud_Leg_Exp captures per capita state and local government expenditures for judicial and legal services (hereinafter "judicial and legal expenditures"). A state's judicial and legal expenditures include spending associated with a state's civil and criminal courts, such as "law libraries, grand juries, petit juries, medical and social service activities (except public defense and probation, where separately identifiable), court reporters, judicial councils, bailiffs, and 'register of wills,' and similar probate functions." These data do not include expenditures from the private sector and are available from the U.S. Department of Justice Bureau Statistics. ${ }^{33}$ Since judicial and legal expenditures are a proxy for litigation costs, we expect the coefficient on Jud_Leg_Exp to be positive; that is, a higher value increases the likelihood of a cap.

$L S \_E m p$ reflects the per capita (in ten thousands) quantity of private sector legal services jobs (including both full-time and part-time employment) in the legal services industry, as defined and reported by the Bureau of Economic Analysis. Danzon (1986) finds a positive correlation between the number of lawyers and the frequency of legal filings. However, she did not find any evidence demonstrating that lawyers have "any systematic impact on the frequency of claims filed" (Danzon, 1986: p. 70). Along the same lines, as Lee, Browne, and Schmit (1994: pp. 302-303) maintain, the relationship between the number of attorneys and the number

\footnotetext{
${ }^{33}$ These data include expenditures for both civil and criminal courts. Unfortunately, data on civil courts alone are not available.
} 
of civil filings is ambiguous. ${ }^{34}$ As the number of legal service jobs increases, the number of lawsuits should increase, ${ }^{35}$ but the cost of legal services should also decrease. In addition, an increase in legal service employment will likely increase the political influence of lawyers, which would work against enactment of a cap. Based on these offsetting factors, we cannot make any a priori predictions regarding the sign of the coefficient on the variable $L S \_E m p$.

The variable $C M \_G S P$ captures per capita construction and manufacturing gross state product (GSP) for each state. ${ }^{36}$ These data were obtained from the Bureau of Economic Analysis. Viscusi (1991: p. 169) finds a correlation between construction and manufacturing activities and products liability insurance premiums. Particularly, he determines that manufacturing activities are responsible for approximately half of all paid products liability insurance premiums, while construction activities account for roughly one quarter of all premiums. Given these findings, there is arguably a correlation between construction and manufacturing activities and the number of accidents. Therefore, we expect the coefficient on CM_GSP to be negative since increases in construction and manufacturing activities ought to increase the overall costs of accidents, thus dissuading legislators from capping punitive damages.

The variable Ins_GSP measures per capita insurance GSP. Grace and Leverty (2008) utilize these data in their investigation of the likelihood that various tort reform measures are held unconstitutional. ${ }^{37}$ These data are also available from the Bureau of Economic Analysis. This variable is included to control for the political influence of the insurance lobby. Given the

\footnotetext{
${ }^{34}$ While legal service employment is not identical to the number of attorneys, the a priori expectations are the same.

${ }^{35}$ This may occur as the result of lawyers accepting marginal cases in the short run, or moving to high-accident jurisdictions in the long run.

${ }^{36}$ Its value is therefore the sum of construction GSP and manufacturing GSP divided by the population of state $j$ for time $t$.

${ }^{37}$ It should be noted that Grace and Leverty (2008) utilized hazard analysis in their study.
} 
anecdotal evidence supporting the proposition that the insurance lobby was influential in the enactment of various tort reform measures, we expect the coefficient on Ins_Emp to be positive.

Following Grace and Leverty (2008), we include two variables to capture the political ideology of each state. The variable Per_Dem_Leg captures the percentage of democrat legislators in state $j$ for time $t$. Its value is the sum of democrat legislators divided by the total number of legislators in each state. These data are obtained from the Partisan Divisions of American State Governments dataset, which is available from the Interuniversity Consortium for Political and Social Research. The coefficient on Per_Dem_Leg is expected to be negative, reflecting the view that democrats generally oppose tort reform while republicans usually support it. In addition, the variable Poli_Index captures the political ideology of residents in state $j$ for time $t$. These data are made available by Berry, et al. (2010). This $[0,1]$ index approximates the unweighted average political ideology of residents in a state by using interest group ideology ratings on candidates in addition to actual election results. Low values of Poli_Index reflect a relatively conservative state, while high values of Poli_Index reflect a state that contains a relatively liberal citizenry. Thus, we expect a negative relationship between this variable and the hazard of cap enactment.

A number of variables are included to capture the economic climate of each state. The variable Unemp captures each state's unemployment rate for time $t$. This variable is included to control for the income effect of tort filings. As Danzon (1986) and Lee, Browne, and Schmit (1994) maintain, the opportunity cost to lawyers and plaintiffs is lower during periods of high unemployment, and as a result, increases in the unemployment rate ought to be associated with lower litigation costs. In contrast, the expected cost of accidents decreases as unemployment 
increases since a customary element of the damage measure for a cause of action in tort is lost wages. Given these offsetting effects, the predicted sign of Unemp is ambiguous.

The variable $P C I$ measures the per capita income for state $j$. We expect it to be negatively correlated with the hazard that a state enacts a punitive damages cap since increases in per capita income increase the cost of accidents. Likewise, the per capita gross state product, $G S P$, proxies for the cost of accidents and therefore should have a negative sign. The variable $N F \_E m p$ is included to control for per capita non-farm employment, since these changes are not properly reflected in the unemployment rate. Like Unemp, the expected sign of this variable is ambiguous since it likely increases both litigation and accident costs. Lastly, since most of the explanatory variables are measured in per capita terms, the variable Pop is included to capture the percent changes in a state's population. Ceteris paribus, increases in population increase activity levels, which ought to increase the number of accidents and hence the litigation rate. At the same time, however, increases in the population growth rate will likely increase the cost of litigation due to greater demand for legal services. Thus, the predicted sign is ambiguous.

We also include dummy variables based on Census region. Since the panel data may suffer from heteroskedasticity or autocorrelation, the standard errors are clustered at the state level.

Table 1 provides summary statistics for the data. The first column ("States Without a Cap") includes the sample average and standard deviation for the explanatory variables for all years before which a cap was enacted (if at all) for every state, while the second column ("States With a Cap") includes the sample average and standard deviation for only those years after (and including) the first year in which a state enacted a cap. The third column provides summary statistics for the entire dataset. 


\section{RESULTS}

Figures 3 and 4 provide the Kaplan-Meier survival estimate and the smoothed hazard estimate, respectively, for cap enactment. As one can infer from Figure 2, these estimates demonstrate that the instantaneous probability of cap enactment has fluctuated considerably since 1981. Moreover, these figures also demonstrate that cap enactment is unlikely for the first few years in which we have available data. These figures support our decision to base the range of our dataset on our understanding of the history of punitive damages caps.

The hazard is run using seven different specifications, the last of which is presumed to be the most reliable. The results from the Cox proportional hazards model are presented in column one of Table 2. Note that only the coefficients on the economic variables exhibit some statistical significance. In particular, the coefficient on the unemployment rate is positive and significant at the $1 \%$ level, while the coefficients on per capita income, GSP, and the population growth rate are all significant at the 5\% level. The negative sign on GSP is in line with the predictions of the model since it serves as a proxy for the cost of accidents. The estimate for insurance GSP is negative and not statistically significant, while the coefficients on judicial and legal expenditures, construction and manufacturing GSP, and legal services employment are all positive and not statistically significant. The adjusted $R^{2}$ is only 0.13 , suggesting that this unrestrictive specification does not explain much variation in the data. However, these results may be unreliable since, as noted, the Cox model does not permit the hazard ratio to be influenced by time. As a result, positing a functional form for the underlying hazard may be necessary.

Accordingly, columns two and three of Table 2 show the estimates when we assume that the underlying hazard function conforms to a Weibull distribution, first with current (column 
two) and then with lagged (column three) covariates. Judicial and legal expenditures are positive in both models and significant (at the 10\% level) in model (3). Legal services employment is positive, statistically significant at the $1 \%$ level, and relatively stable under both specifications. This provides some evidence that the effect of increased court caseloads dominates the reduction in the cost of legal services, though as noted, it could also reflect the political influence of the lawyer's lobby. Construction and manufacturing GSP is positive under both specifications, but neither coefficient is statistically significant. Insurance GSP is negative under both specifications, but neither estimate is statistically significant.

The estimates in columns two and three, however, are susceptible to measurement error. In particular, the legislative process is sometimes slow and methodical, and as a result, it may take many years for a state legislature to approve and implement a proposed cap on punitive damages. Therefore, to control for measurement error, we use three-year lagged averages as explanatory variables (columns four through seven). ${ }^{38}$ Under the first of the specifications utilizing three-year lagged averages (column four), we do not include a shared heterogeneity term and we dismiss the possibility that the Liebeck ruling served as a catalyst for cap enactment. Under this specification, the coefficients for judicial and legal expenditures and legal services employment continue to be positive and statistically significant at the $5 \%$ level. The coefficient on the political index is negative and significant at the 5\% level, supporting the conjecture that a democrat-dominated electorate opposes tort reform. The coefficient on GSP is negative, also as expected, and it is significant at the 5\% level. Lastly, the coefficient on non-farm employment is positive and significant at the $5 \%$ level.

\footnotetext{
${ }^{38}$ Note that the percentage of democrat legislators is not three-year lagged averaged. Rather, only one-period lagged values are used for this political control.
} 
When a dummy variable is introduced to control for the possible influence of the Liebeck ruling, the estimates are relatively stable between the specification including the dummy variable (column five), and the specification excluding the dummy variable (column four). Judicial and legal expenditures and legal services employment remain positive, stable, and statistically significant at the 5\% level. The estimates on the political index, GSP, and non-farm employment are also relatively stable and retain their statistical significance at the 5\% level. However, the introduction of the Liebeck dummy results in a statistically significant positive estimate (at the $5 \%$ level) for the unemployment rate. The Liebeck dummy itself, however, is not significant.

Unlike the specifications using current and lagged values, these estimates are less likely to suffer from measurement error. At the same time, however, they are susceptible to bias from unobserved heterogeneity. To control for this possibility, the final two columns in Table 2 provide estimates using three-year lagged averages with a shared gamma heterogeneity term. These results are the most precise of any of the specifications since they are least likely to suffer from omitted variable bias. Column six provides estimates without the Liebeck dummy. After controlling for unobserved heterogeneity, the sign on judicial and legal expenditures is positive and stable, though it is now only significant at the $10 \%$ level. The estimate for legal services employment is positive, relatively stable, and statistically significant at the $1 \%$ level. Insurance GSP and construction and manufacturing GSP are not statistically significant, and neither is of the expected sign. The political index is negative, stable, and significant at the $5 \%$ level. The percent of democrat legislators is also negative, as expected, but it is not statistically significant. Of the economic controls, only the estimates for unemployment and non-farm employment are statistically significant; both are positive and significant at the 5\% level. 
When the Liebeck dummy is incorporated into the hazard analysis with a shared gamma heterogeneity term (column seven), the estimates remain relatively stable. The coefficient on judicial and legal expenditures remains positive and significant at the $10 \%$ level. The estimate for legal services employment is also positive and it is significant at the $5 \%$ level. Insurance GSP and construction and manufacturing GSP are both negative, but neither is statistically significant. However, both political controls are negative and significant: the political index at the $5 \%$ level and the percent of democrat legislators at the $10 \%$ level.

Some economic controls also exhibit statistical significance. Like the specification without the Liebeck dummy, the unemployment rate and non-farm employment are positive and significant at the 5\% level. The former most likely reflects the reduction in the opportunity cost of litigation that results from increases in unemployment, while the latter likely reflects the increases in court-ordered damages that result from lost wages or lost earning capacity in periods of high job growth. The coefficient on GSP is negative, as expected, and significant at the $10 \%$ level. Like the specification without a shared heterogeneity term, the Liebeck dummy does not exhibit statistical significance. ${ }^{39}$ Finally, under all specifications, punitive damages caps are least likely to be enacted in the western part of the country, though the Census Region dummies do not exhibit statistical significance under any of the models.

Taken as a whole, these results provide some support for the economic model. The estimate for judicial and legal expenditures was positive across all specifications and was statistically significant under a majority of the specifications. This result is consistent with the

\footnotetext{
${ }^{39}$ It should be noted that despite the apparent bimodal nature of the estimated hazard function (see Figure 4), the hazard analyses utilized in this paper properly relied upon the Weibull hazard function. All estimates obtained utilizing the Weibull hazard were able to reject the null hypothesis (at the 1\% level) of the Wald test. Interestingly, the Weibull shape parameter ranged between 3.6 and 4.0 in the four specifications using three-year lagged averages. This result suggests that the longer a state "survives" before enacting a cap, the more likely it is that it will enact a cap on punitive damages. In other words, we should expect to see more caps on punitive damages.
} 
prediction that increases in the cost of litigation encourage legislators to enact caps on punitive damages. In addition, the positive, significant (at the $5 \%$ or better level), and stable estimate on legal services employment suggests that increases in the size of the legal services sector are associated with increases in litigation costs, and hence with an increase in the likelihood of a cap. Although construction and manufacturing GSP did not influence cap enactment under any of our specifications, another proxy for damages, state GSP, was negative and significant under several specifications. Finally, as expected, states with a high percentage of democrat legislators and those with a large proportion of democratically-aligned residents were less likely to enact caps on punitive damages.

\section{CONCLUSION}

Under the traditional economic model of punitive damages, which views them as a solution to the problem of underdetection, there is no theoretical justification for imposing a cap on their amount. However, by incorporating litigation costs into the model, we were able to provide a theoretical justification for a statutory cap on damages as a way of balancing the deterrence benefits against the cost of additional suits. We tested the predictions of the theoretical model by running Cox and parametric hazard analyses on a rich panel dataset covering 27 years. After controlling for measurement error and unobserved heterogeneity, we found some evidence that increases in judicial and legal expenditures (a proxy for litigation costs) increased the likelihood of cap enactment, and that higher state GSP (a proxy for damages) reduced the likelihood of a cap. We also found evidence that increases in the quantity of legal services increased the hazard of cap enactment, and that democratic-leaning states were less likely to enact caps. 


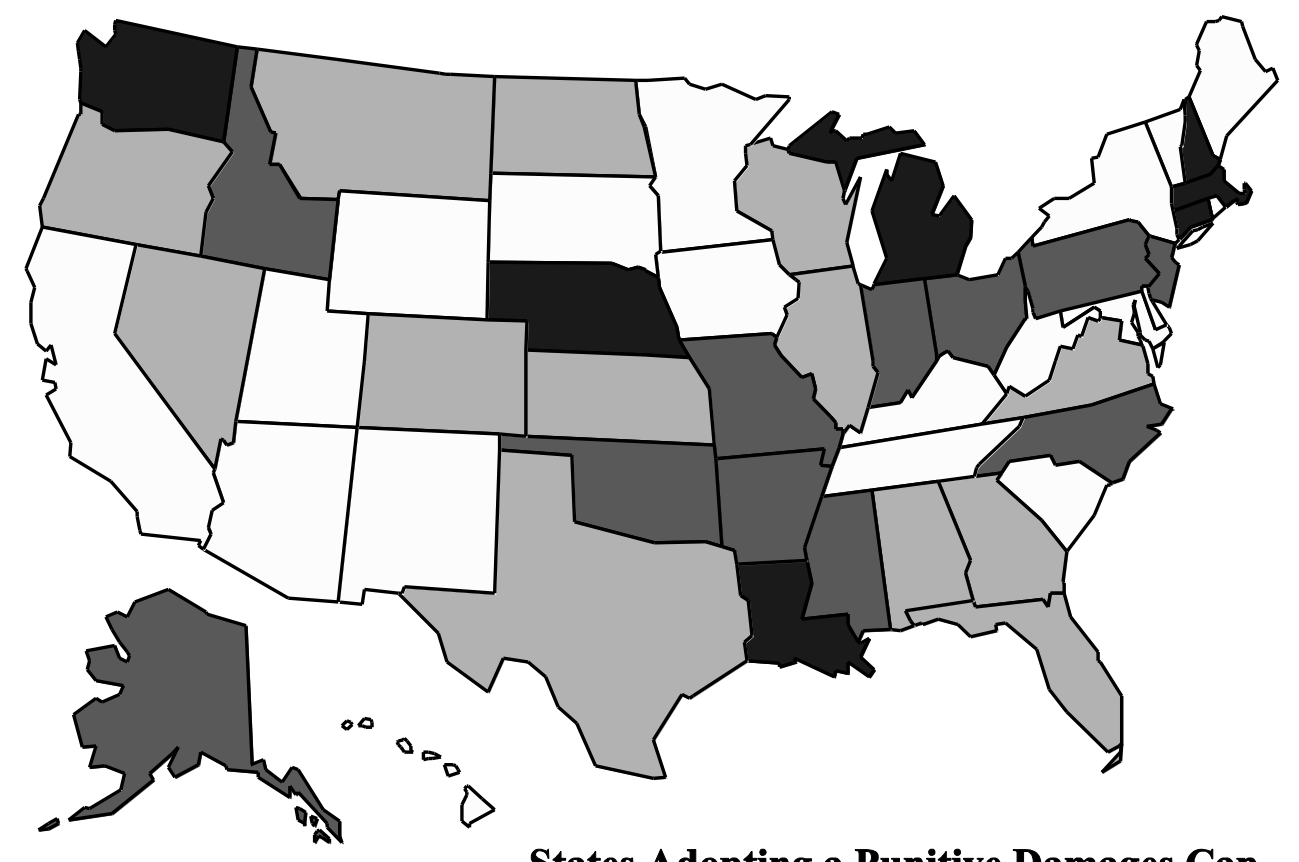

States Adopting a Punitive Damages Cap

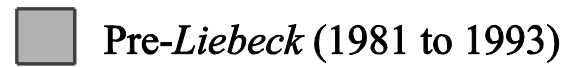

Post-Liebeck (1994 to 2008)

Pre-1981

$\square$ No Cap

Figure 1. Time periods during which states imposed punitive damage caps. 


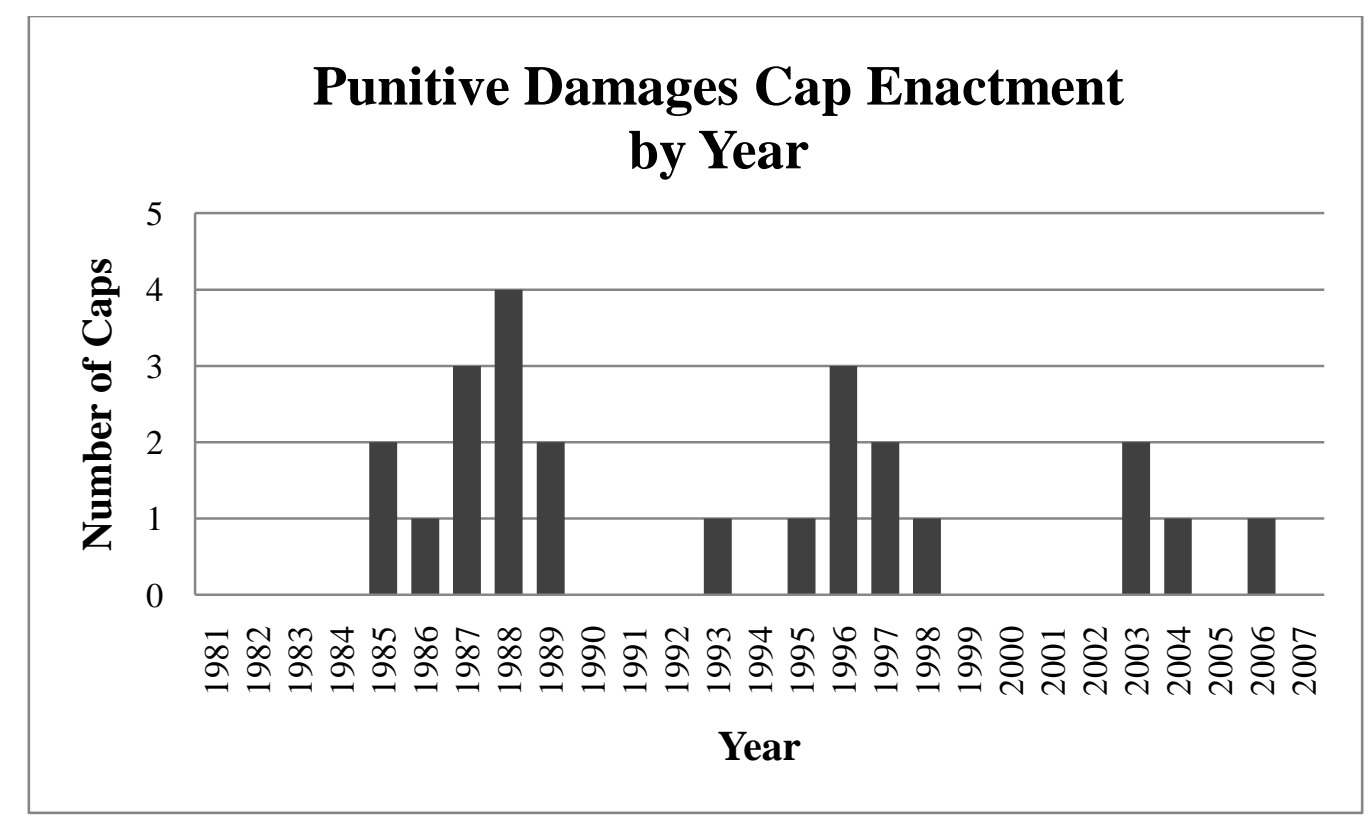

Figure 2. Caps on punitive damages enacted by year, following Avraham's (2010) methodology.

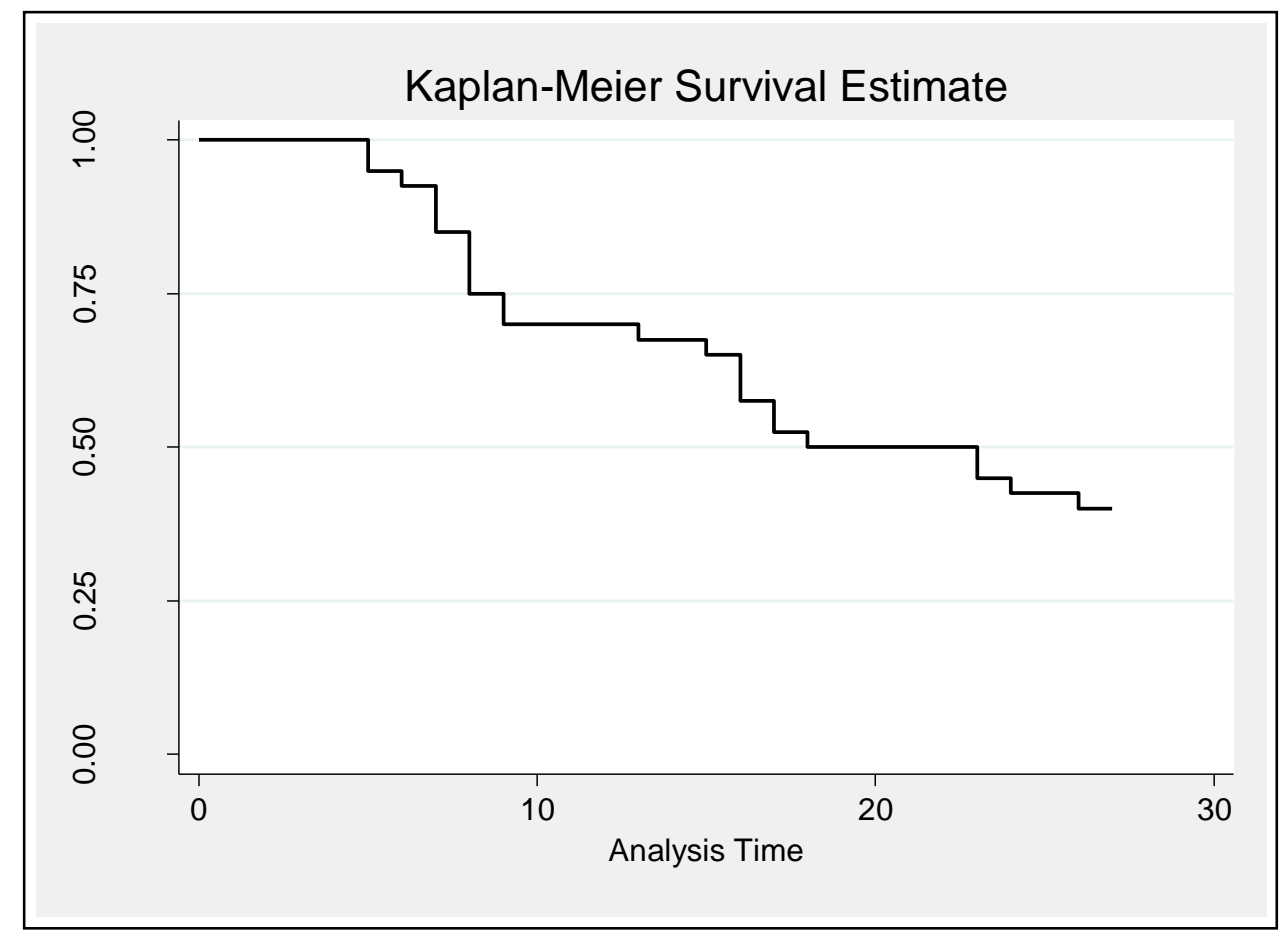

Figure 3. Instantaneously probability of cap enactment for all analysis times, given that enactment has not already occurred. 


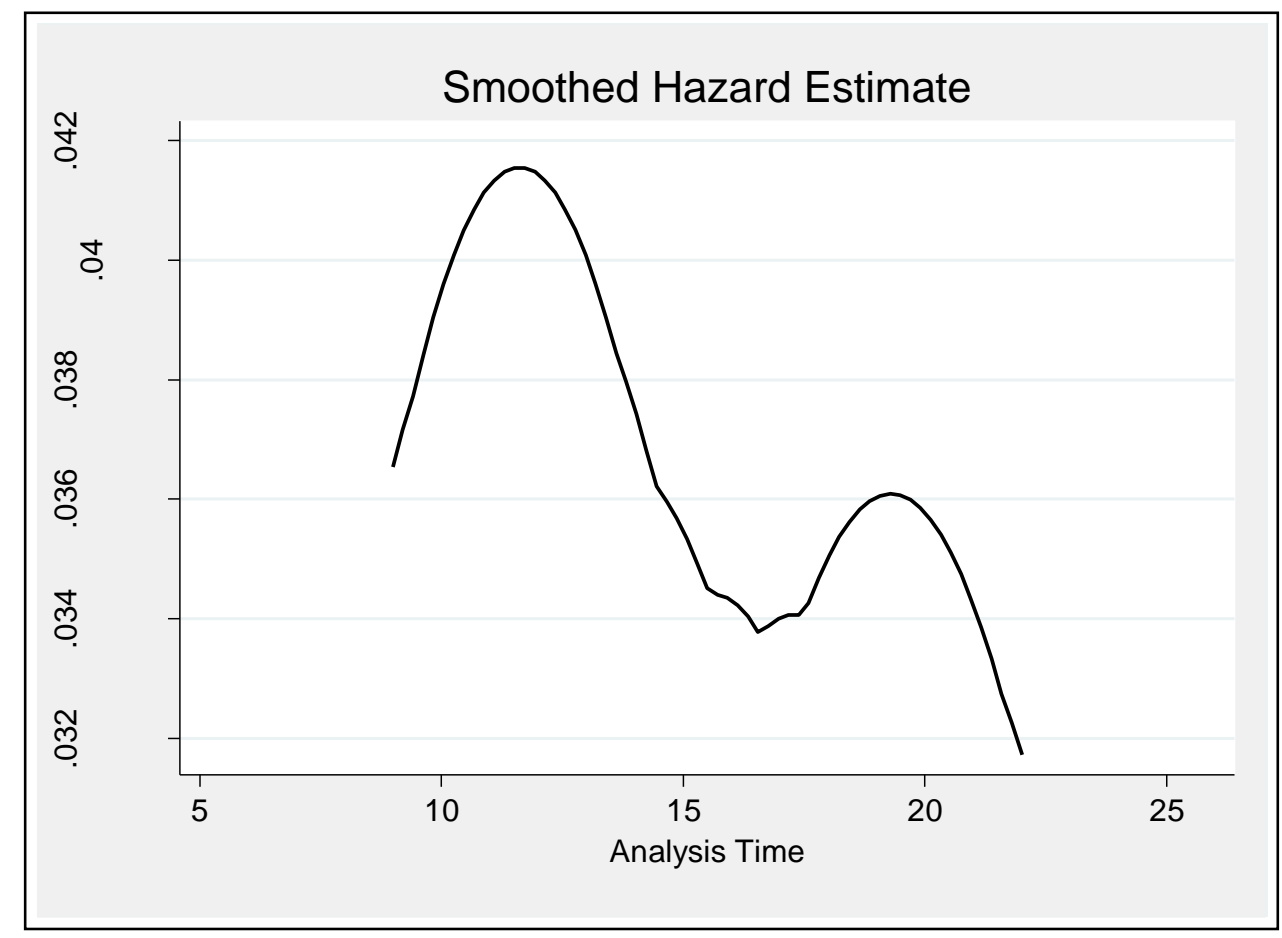

Figure 4. The hazard of cap enactment for all analysis times, given that enactment has not already occurred. 


\begin{tabular}{|c|c|c|c|c|c|c|}
\hline \multicolumn{7}{|c|}{$\begin{array}{c}\text { Table 1: Summary Statistics } \\
\text { 40 State characteristics (1981 to 2007) }\end{array}$} \\
\hline \multirow[b]{2}{*}{ Variable } & \multicolumn{2}{|c|}{$\begin{array}{l}\text { States Without } \\
\text { a Cap* }\end{array}$} & \multicolumn{2}{|c|}{$\begin{array}{l}\text { States With } \\
\text { a Cap** }\end{array}$} & \multicolumn{2}{|c|}{ All Data } \\
\hline & $\mathbf{N}$ & $\begin{array}{c}\text { Mean } \\
\text { (St. Dev.) }\end{array}$ & $\mathbf{N}$ & $\begin{array}{l}\text { Mean } \\
\text { (St. Dev.) }\end{array}$ & $\mathbf{N}$ & $\begin{array}{l}\text { Mean } \\
\text { (St. Dev.) }\end{array}$ \\
\hline $\begin{array}{l}\text { Judicial \& Legal Expenditures, } \\
\text { per capita (Jud_Leg_Exp) }\end{array}$ & 681 & $\begin{array}{c}(0.0567) \\
(0.0431)\end{array}$ & 319 & $\begin{array}{l}(0.0772) \\
(0.0367)\end{array}$ & 1000 & $\begin{array}{l}(0.0633) \\
(0.0422)\end{array}$ \\
\hline $\begin{array}{l}\text { Legal Services Employment, } \\
\text { per capita }(10,000 \text { s })\left(L S \_E m p\right)\end{array}$ & 595 & $\begin{array}{l}(39.6769) \\
(11.4412)\end{array}$ & 205 & $\begin{array}{c}(43.253) \\
(8.2483)\end{array}$ & 800 & $\begin{array}{c}(40.5933) \\
(10.8225)\end{array}$ \\
\hline $\begin{array}{l}\text { Construction \& Manufacturing GSP, } \\
\text { per capita }\left(C M \_G S P\right)\end{array}$ & 719 & $\begin{array}{c}(0.0047) \\
(0.0018)\end{array}$ & 361 & $\begin{array}{c}(0.0059) \\
(0.0021)\end{array}$ & 1080 & $\begin{array}{l}(0.0051) \\
(0.002)\end{array}$ \\
\hline $\begin{array}{l}\text { Insurance GSP, } \\
\text { per capita (Ins_GSP) }\end{array}$ & 719 & $\begin{array}{c}(0.0006) \\
(0.0007)\end{array}$ & 361 & $\begin{array}{c}(0.0007) \\
(0.0003)\end{array}$ & 1080 & $\begin{array}{c}(0.0006) \\
(0.0006)\end{array}$ \\
\hline $\begin{array}{l}\text { Political Index } \\
(\text { Poli_Index })\end{array}$ & 719 & $\begin{array}{l}(50.8883) \\
(15.6986)\end{array}$ & 361 & $\begin{array}{c}(46.3015) \\
(10.7948)\end{array}$ & 1080 & $\begin{array}{c}(49.3551) \\
(14.4068)\end{array}$ \\
\hline $\begin{array}{l}\text { Percent Democrat Legislature } \\
(\text { Per_Dem_Leg) }\end{array}$ & 719 & $\begin{array}{c}(0.5862) \\
(0.1733)\end{array}$ & 361 & $\begin{array}{c}(0.4956) \\
(0.1168)\end{array}$ & 1080 & $\begin{array}{c}(0.5559) \\
(0.1624)\end{array}$ \\
\hline $\begin{array}{l}\text { Unemployment Rate } \\
\text { (Unemp) }\end{array}$ & 719 & $\begin{array}{c}(6.0868) \\
(2.1614)\end{array}$ & 361 & $\begin{array}{c}(5.0512) \\
(1.2171)\end{array}$ & 1080 & $\begin{array}{l}(5.7406) \\
(1.96)\end{array}$ \\
\hline $\begin{array}{l}\text { Income, } \\
\text { per capita }(\$ 1,000 \mathrm{~s})(P C I)\end{array}$ & 719 & $\begin{array}{l}(19.9086) \\
(7.9295)\end{array}$ & 361 & $\begin{array}{l}(26.9495) \\
\quad(7.088)\end{array}$ & 1080 & $\begin{array}{c}(22.2621) \\
(8.3453)\end{array}$ \\
\hline $\begin{array}{l}\text { GSP, } \\
\text { per capita }(G S P)\end{array}$ & 719 & $\begin{array}{c}(0.0237) \\
(0.0103)\end{array}$ & 361 & $\begin{array}{c}(0.0312) \\
(0.0089)\end{array}$ & 1080 & $\begin{array}{c}(0.0262) \\
(0.0104)\end{array}$ \\
\hline $\begin{array}{l}\text { Non-farm Employment, } \\
\text { per capita }\left(N F_{-} E m p\right)\end{array}$ & 719 & $\begin{array}{l}(0.5506) \\
(0.058)\end{array}$ & 361 & $\begin{array}{c}(0.5856) \\
(0.0444)\end{array}$ & 1080 & $\begin{array}{c}(0.5623) \\
(0.0563)\end{array}$ \\
\hline $\begin{array}{l}\text { Population Growth Rate } \\
(\text { Pop_GR })\end{array}$ & 719 & $\begin{array}{c}(0.0094) \\
(0.0099)\end{array}$ & 361 & $\begin{array}{c}(0.0129) \\
(0.0116)\end{array}$ & 1080 & $\begin{array}{c}(0.0105) \\
(0.0106)\end{array}$ \\
\hline $\begin{array}{l}\text { West Dummy } \\
(\text { West_D) }\end{array}$ & 719 & $\begin{array}{c}(0.2406) \\
(0.4278)\end{array}$ & 361 & $\begin{array}{c}(0.2687) \\
(0.4439)\end{array}$ & 1080 & $\begin{array}{l}(0.25) \\
(0.4332)\end{array}$ \\
\hline $\begin{array}{l}\text { Midwest Dummy } \\
\text { (Midwest_D) }\end{array}$ & 719 & $\begin{array}{c}(0.2281) \\
(0.4199)\end{array}$ & 361 & $\begin{array}{c}(0.2936) \\
(0.4561)\end{array}$ & 1080 & $\begin{array}{l}(0.25) \\
(0.4332)\end{array}$ \\
\hline $\begin{array}{l}\text { South Dummy } \\
(\text { South_D })\end{array}$ & 719 & $\begin{array}{l}(0.338) \\
(0.4733) \\
\end{array}$ & 361 & $\begin{array}{l}(0.374) \\
(0.4845) \\
\end{array}$ & 1080 & $\begin{array}{c}(0.35) \\
(0.4772) \\
\end{array}$ \\
\hline
\end{tabular}

* Includes data for all years in which the variable PD_Cap $=0$.

** Includes data for all years in which the variable PD_Cap $=1$. 


\begin{tabular}{|c|c|c|c|c|c|c|c|}
\hline \multicolumn{6}{|c|}{$\begin{array}{l}\text { Table 2: Regression Results } \\
\text { Lag-Avg. includes } 1^{\text {st }}, 2^{\text {nd }} \text {, and } 3^{\text {rd }} \text { lags }\end{array}$} & \multicolumn{2}{|c|}{$\begin{array}{r}* * *(\mathrm{p} \text {-value }<.01) \\
* *(\mathrm{p} \text {-value }<.05) \\
*(\mathrm{p} \text {-value }<.10) \\
\end{array}$} \\
\hline Variable & (1) & (2) & (3) & (4) & (5) & (6) & (7) \\
\hline Jud_Leg_Exp & $\begin{array}{c}14.9739 \\
(13.5869)\end{array}$ & $\begin{array}{c}18.22 \\
(12.3322)\end{array}$ & $\begin{array}{c}25.4342 * * * \\
(9.3738)\end{array}$ & $\begin{array}{c}30.8593 * * \\
(14.4765)\end{array}$ & $\begin{array}{c}29.8336 * * \\
(13.05)\end{array}$ & $\begin{array}{l}30.4766^{*} \\
(17.9408)\end{array}$ & $\begin{array}{l}29.4717 * \\
(17.3272)\end{array}$ \\
\hline$L S \_E m p$ & $\begin{array}{c}0.0281 \\
(0.03)\end{array}$ & $\begin{array}{c}0.0968 * * * \\
(0.0374)\end{array}$ & $\begin{array}{c}0.1073 * * * \\
(0.0368)\end{array}$ & $\begin{array}{c}0.1187 * * \\
(0.0505)\end{array}$ & $\begin{array}{c}0.1043 * * \\
(0.0482)\end{array}$ & $\begin{array}{c}0.1206 * * * \\
(0.0452)\end{array}$ & $\begin{array}{c}0.1067 * * \\
(0.0467)\end{array}$ \\
\hline$C M \_G S P$ & $\begin{array}{c}19.5001 \\
(246.7697)\end{array}$ & $\begin{array}{c}39.2162 \\
(191.985)\end{array}$ & $\begin{array}{c}52.4795 \\
(225.6833)\end{array}$ & $\begin{array}{c}24.5161 \\
(285.5201)\end{array}$ & $\begin{array}{l}-19.133 \\
(290.87)\end{array}$ & $\begin{array}{c}22.7801 \\
(264.4787)\end{array}$ & $\begin{array}{c}-20.353 \\
(265.095)\end{array}$ \\
\hline$I n s \_G S P$ & $\begin{array}{c}-146.32 \\
(1090.088)\end{array}$ & $\begin{array}{c}-1043 \\
(1093.849)\end{array}$ & $\begin{array}{c}-1269.5 \\
(1233.648)\end{array}$ & $\begin{array}{c}-315.76 \\
(480.7479)\end{array}$ & $\begin{array}{c}-221.92 \\
(481.5517)\end{array}$ & $\begin{array}{c}-314.9 \\
(684.2682)\end{array}$ & $\begin{array}{c}-217.34 \\
(673.3557)\end{array}$ \\
\hline Poli_Index & $\begin{array}{l}-0.0466 \\
(0.0348)\end{array}$ & $\begin{array}{l}-0.0265 \\
(0.0212)\end{array}$ & $\begin{array}{l}-0.0369 \\
(0.0258)\end{array}$ & $\begin{array}{c}-0.0234 * * \\
(0.0118)\end{array}$ & $\begin{array}{c}-0.0257 * * \\
(0.0129)\end{array}$ & $\begin{array}{c}-0.0232 * * \\
(0.0106)\end{array}$ & $\begin{array}{c}-0.0255^{* *} \\
(0.011)\end{array}$ \\
\hline Per_Dem_Leg & $\begin{array}{c}-3.0895 \\
(2.351)\end{array}$ & $\begin{array}{l}-2.8946 \\
(2.0263)\end{array}$ & $\begin{array}{c}-3.9518 * \\
(2.2819)\end{array}$ & $\begin{array}{c}-1.263 \\
(0.8155)\end{array}$ & $\begin{array}{l}-1.3903 \\
(0.8507)\end{array}$ & $\begin{array}{l}-3.9761 \\
(2.4334)\end{array}$ & $\begin{array}{c}-4.4285^{*} \\
(2.4641)\end{array}$ \\
\hline Unemp & $\begin{array}{c}0.6385^{* * * *} \\
(0.234)\end{array}$ & $\begin{array}{c}0.1998 \\
(0.1701)\end{array}$ & $\begin{array}{c}0.4255^{* *} \\
(0.1938)\end{array}$ & $\begin{array}{c}0.6771 \\
(0.2777)\end{array}$ & $\begin{array}{c}0.7655^{* *} \\
(0.3104)\end{array}$ & $\begin{array}{l}0.661 * * \\
(0.2841)\end{array}$ & $\begin{array}{l}0.753 * * \\
(0.2955)\end{array}$ \\
\hline$P C I$ & $\begin{array}{c}0.4667 * * \\
(0.1894)\end{array}$ & $\begin{array}{l}-0.0815 \\
(0.1949)\end{array}$ & $\begin{array}{c}-0.1166 \\
(0.187)\end{array}$ & $\begin{array}{l}-0.134 \\
(0.251)\end{array}$ & $\begin{array}{c}-0.023 \\
(0.2228)\end{array}$ & $\begin{array}{c}-0.1452 \\
(0.276)\end{array}$ & $\begin{array}{l}-0.0368 \\
(0.2785)\end{array}$ \\
\hline$G S P$ & $\begin{array}{l}-364.14 * * \\
(185.7998)\end{array}$ & $\begin{array}{c}-202.86 \\
(158.9478)\end{array}$ & $\begin{array}{l}-268.64 * * \\
(122.1742)\end{array}$ & $\begin{array}{c}-332.66 * * \\
(161.9653)\end{array}$ & $\begin{array}{c}-348.83 * * \\
(151.2266)\end{array}$ & $\begin{array}{c}-325.83 \\
(205.1172)\end{array}$ & $\begin{array}{c}-341.72 * \\
(194.3253)\end{array}$ \\
\hline$N F \_E m p$ & $\begin{array}{c}14.71 \\
(8.9858)\end{array}$ & $\begin{array}{l}13.1335 \\
(9.5462)\end{array}$ & $\begin{array}{c}20.5092 * * \\
(9.9056)\end{array}$ & $\begin{array}{c}29.6908 * * \\
(13.9551)\end{array}$ & $\begin{array}{c}29.3532 * * \\
(13.776)\end{array}$ & $\begin{array}{c}29.3979 * * \\
(13.0785)\end{array}$ & $\begin{array}{c}29.1984 * * \\
(13.2597)\end{array}$ \\
\hline Pop_GR & $\begin{array}{c}40.0537 * * \\
(18.5784)\end{array}$ & $\begin{array}{c}24.4217 \\
(31.5438)\end{array}$ & $\begin{array}{c}29.2612 \\
(27.8826)\end{array}$ & $\begin{array}{c}30.4402 \\
(28.3079)\end{array}$ & $\begin{array}{l}39.6209 \\
(31.2118)\end{array}$ & $\begin{array}{c}26.8177 \\
(33.6843)\end{array}$ & $\begin{array}{c}36.1686 \\
(34.4805)\end{array}$ \\
\hline Liebeck dummy & & & & & $\begin{array}{l}-1.1079 \\
(0.7563)\end{array}$ & & $\begin{array}{l}-1.1489 \\
(0.9099)\end{array}$ \\
\hline West_D & $\begin{array}{c}-1.088 \\
(1.2998)\end{array}$ & $\begin{array}{l}-0.1733 \\
(1.3478)\end{array}$ & $\begin{array}{l}-0.9533 \\
(1.4794)\end{array}$ & $\begin{array}{l}-1.9754 \\
(1.8128)\end{array}$ & $\begin{array}{l}-2.2953 \\
(1.9567)\end{array}$ & $\begin{array}{c}-1.9505 \\
(1.5)\end{array}$ & $\begin{array}{l}-2.2659 \\
(1.5412)\end{array}$ \\
\hline Midwest_D & $\begin{array}{c}0.946 \\
(0.8455)\end{array}$ & $\begin{array}{c}1.5877 \\
(1.0668)\end{array}$ & $\begin{array}{c}1.4196 \\
(1.0636)\end{array}$ & $\begin{array}{c}0.9598 \\
(1.0618)\end{array}$ & $\begin{array}{l}0.8503 \\
(0.993)\end{array}$ & $\begin{array}{c}0.9601 \\
(1.1255)\end{array}$ & $\begin{array}{c}0.8675 \\
(1.1356)\end{array}$ \\
\hline South_D & $\begin{array}{c}0.7909 \\
(1.0126)\end{array}$ & $\begin{array}{l}1.5734 \\
(1.165)\end{array}$ & $\begin{array}{c}1.462 \\
(1.2804)\end{array}$ & $\begin{array}{c}0.7664 \\
(1.3561)\end{array}$ & $\begin{array}{c}0.653 \\
(1.3379)\end{array}$ & $\begin{array}{c}0.8073 \\
(1.4093)\end{array}$ & $\begin{array}{c}0.7186 \\
(1.41)\end{array}$ \\
\hline Constant & & $\begin{array}{c}-13.881 * * \\
(6.6433)\end{array}$ & $\begin{array}{c}-18.012 * * * * \\
(7.0357)\end{array}$ & $\begin{array}{c}-339.73 \\
(484.0968)\end{array}$ & $\begin{array}{c}-247.48 \\
(484.4177)\end{array}$ & $\begin{array}{c}-337.26 \\
(685.1062)\end{array}$ & $\begin{array}{c}-241.31 \\
(674.0642)\end{array}$ \\
\hline Covariates & Current & Current & Lagged & Lag-Avg. & Lag-Avg. & Lag-Avg. & Lag-Avg. \\
\hline Hazard & Proportional & Weibull & Weibull & Weibull & Weibull & Weibull & Weibull \\
\hline Weibull shape $(\alpha)$ & & 2.8427 & 3.2516 & 3.5712 & 4.0261 & 3.5547 & 4.0489 \\
\hline Heterogeneity term & & & & & & Gamma & Gamma \\
\hline $\mathrm{R}^{2}$ & 0.1288 & & & & & & \\
\hline Log Likelihood & -59.6526 & -32.8970 & -30.7342 & -27.8143 & -27.1047 & -27.6116 & -26.8351 \\
\hline
\end{tabular}




\section{References}

Ausness, Richard C. 1985. Retribution and Deterrence: The Role of Punitive Damages in Products Liability Litigation. Kentucky Law Journal 74: 1-125.

Avraham, Ronen. 2007. An Empirical Study of the Impact of Tort Reforms on Medical Malpractice Settlement Payments. Journal of Legal Studies 34: S183-S229.

2010. Database of State Tort Law Reforms (DSTLR 3rd). Northwestern Law and Economics Research Paper No. 06-08; University of Texas Law, Law and Economics Research Paper No. 184. Available at SSRN: http://ssrn.com/abstract=902711.

Berry, William D., Evan J. Ringquist, Richard C. Fording and Russell L. Hanson. 2010. Revised 1960-2008 Citizen Ideology Series 1998, extending Berry, William D., Evan J.

Ringquist, Richard C. Fording and Russell L. Hanson. 1998. Measuring Citizen and Government Ideology in the American States, 1960-93. American Journal of Political Science 42: 327-48.

Biggar, Darryl. 1995. A Model of Punitive Damages in Tort. International Review of Law and Economics 15: 1-24.

Born, Patricia, W. Kip Viscusi and Tom Baker. 2009. The Effects of Tort Reform on Medical Malpractice Insurers' Ultimate Losses. Journal of Risk and Insurance 76: 197-219.

Brown, Robert W., R. Todd Jewell, and Jerrell Richer. 1996. Endogenous Alcohol Prohibition and Drunk Driving. Southern Economic Journal 62: 1043-53.

Cooter, Robert D. 1982. Economic Analysis of Punitive Damages. Southern California Law Review 56: 79-101.

1989. Punitive Damages for Deterrence: When and How Much. Alabama Law Review 40: 1143-1196.

Chu, C.Y. Cyrus and Chen-Ying Huang. 2004. On the Definition and Efficiency of Punitive Damages. International Review of Law and Economics 24: 241-54.

Danzon, Patricia M. 1986. The Frequency and Severity of Medical Malpractice Claims: New Evidence. Law and Contemporary Problems 49: 57-84.

De Figueiredo, Jr., Rui J. P. and Richard G. Vanden Bergh. 2004. The Political Economy of State-Level Administrative Procedure Acts. Journal of Law and Economics 47: 569-588.

Eisenberg, Theodore, John Goerdt, Brian Ostrom, David Rottman, and Martin T. Wells. 1997. The Predictability of Punitive Damages. Journal of Legal Studies 26: 623-661. 
Galanter, Marc. 1986. The Day After the Litigation Explosion. Maryland Law Review 46: 3-39.

Grace, Martin F. and J. Tyler Leverty. How Tort Reform Affects Insurance Markets. Northwestern Law Research Symposium on Insurance Markets and Regulation (April 15, 2008) (under second round of review at Journal of Law and Economics).

Greene, Edith, Jane Goodman, and Elizabeth F. Loftus. 1991. Jurors’ Attitudes About Civil Litigation and the Size of Damages Awards. American University Law Review 40: 80520.

Hersch, Joni and W. Kip Viscusi. 2004. Punitive Damages: How Judges and Juries Perform. Journal of Legal Studies 33: 1-36.

Hylton, Keith N. 1990. The Influence of Litigation Costs on Deterrence under Strict Liability and under Negligence. International Review of Law and Economics 10: 161-171.

Karpoff, Jonathan and John Lott. 1999. On the Determinants and Importance of Punitive Damage Awards. Journal of Law and Economics. 42: 527-573.

Klein, John P. and Melvin L. Moeschberger. 1997. Survival Analysis: Techniques for Censored and Truncated Data. New York: Springer.

Landes, William and Richard Posner. 1987. The Economic Structure of Tort Law. Cambridge, MA: Harvard Univ. Press.

Lee, Han-Duck, Mark J. Browne, and Joan T. Schmit. 1994. How Does Joint and Several Tort Reform Affect the Rate of Tort Filings? Evidence from the State Courts. Journal of Risk and Insurance 61: 295-316.

McCann, Michael, William Haltom, and Anne Bloom. 2001. Law and Society Symposium: Java Jive: Genealogy of a Juridical Icon. Univ. of Miami Law Review 56: 113-78.

Nanda, Anupam. 2006. Property Condition Disclosure Law: Why Did States Mandate 'Seller Tell All'?. Department of Economics Working Paper, University of Connecticut. (available at http://www.econ.uconn.edu/working/2006-16.pdf.)

O’Connell, Jeffrey. 1987. Symposium Issues in Tort Reform: Balanced Proposals for Product Liability Reform. Ohio State Law Journal 48: 317-28.

Polinsky, A. Mitchell. 1997. Are Punitive Damages Really Insignificant, Predictable, and Rational? A Comment on Eisenberg et al. Journal of Legal Studies 26: 663-677. and Steven S. Shavell. 1998. Punitive Damages: An Economic Analysis. Harvard Law Review 111: 869-962. 
. 2000. The Economic Theory of Public Enforcement of Law. Journal of Economic Literature 38: 45-76.

Rubin, Paul and Joanna Shepherd. 2007. Tort Reform and Accidental Deaths. Journal of Law and Economics 50: 221-238.

Rustad, Michael and Thomas Koenig. 1993. The Historical Continuity of Punitive Damages Awards: Reforming the Tort Reformers. American University Law Review 42: 12691333.

Schmit, Joan T., S. Travis Pritchett, and Paige Fields. 1988. Punitive Damages: Punishment or Further Compensation? Journal of Risk and Insurance 55: 453-66.

Shanley, Michael. 1991. The Distribution of Post-Trial Awards. Journal of Legal Studies 20: 463-481.

Sharkey, Catherine M. 2003. Punitive Damages as Societal Damages. Yale Law Journal 113: 347-453.

Shavell, Steven. 1982. The Social versus Private Incentive to Bring Suit in a Costly Legal System. Journal of Legal Studies 11: 333-339. Press.

Viscusi, W. Kip. 1991. The Dimensions of the Product Liability Crisis. Journal of Legal Studies 20: $147-177$. $1405-1455$.

. 2004. The Blockbuster Punitive Damages Awards. Emory Law Journal 53:

and Patricia H. Born. 2005. Damages Caps, Insurability, and the Performance of Medical Malpractice Insurance. Journal of Risk and Insurance 72: 23-43.

Yoon, Albert. 2001. Damage Caps and Civil Litigation: An Empirical Study of Medical Malpractice Litigation in the South. American Law and Economics Review 3: 199-227. 